\title{
ANALISIS PERBANDINGAN KEPUTUSAN PEMBELIAN SEPEDA MOTOR MEREK YAMAHA DAN HONDA (STUDI KASUS DESA AEK TUHUL KECAMATAN PADANGSIDIMPUAN BATUNADUA)
}

\author{
Oleh: \\ Darwis Harahap, Nurul Izzah Lubis, Kusti Ardinah \\ IAIN Padangsidimpuan \\ Jl. T. Rizal Nurdin Km. 4,5 Kelurahan Sihitang \\ Padangsidimpuan
}

\begin{abstract}
ABSTRAK
Persaingan bisnis di dunia otomotif khususnya sepeda motor saat ini semakin ketat, hal ini ditandai dengan adanya banyak varian produk dengan merek yang beraneka ragam yang diperkenalkan dipasaran. Kebutuhan alat transportasi yang semakin meningkat membuat sepeda motor menjadi transportasi yang digemari di kalangan masyarakat, yaitu Yamaha dan Honda. Sepeda motor merek Honda merupakan sepeda motor yang paling banyak digunakan oleh masyarakat dibandingkan dengan sepeda motor merek Yamaha. Dampak positif yang terjadi dengan adanya fenomena ini adalah sepeda motor banyak digunakan karena tidak hanya merupakan suatu kebutuhan saja, namun juga karena praktis, irit bahan bakar, hemat, perawatan yang murah, dan lebih efektif. Rumusan masalah penelitian ini adalah apakah terdapat perbedaan keputusan pembelian yang signifikan dari segi harga, merek, dan kualitas produk dalam keputusan pembelian sepeda motor merek Yamaha dan Honda. Tujuan penelitian ini adalah untuk mengetahui perbedaan keputusan pembelian yang signifikan dari segi harga, merek, dan kualitas produk dalam keputusan pembelian sepeda motor merek Yamaha dan Honda.

Pembahasan penelitian ini berkaitan dengan bidang ilmu manajemen pemasaran. Sehubungan dengan itu, pendekatan yang dilakukan adalah teori-teori yang berkaitan dengan harga, merek, kualitas produk, dan keputusan pembelian.

Penelitian ini merupakan penelitian kuantitatif, jenis penelitiannya yaitu analisis komparatif atau analisis perbedaan (perbandingan). Adapun instrumen pengumpulan data melalui angket (kuesioner). Analisis data yang digunakan adalah uji Independent Sample TTest.

Berdasarkan hasil penelitian ini diperoleh hasil signifikansi untuk variabel harga sebesar 0,077 yaitu $(0,077<0,1)$, maka $\mathrm{H}_{\mathrm{a}}$ diterima dan $\mathrm{H}_{\mathrm{o}}$ ditolak. Hasil signifikansi untuk variabel merek sebesar 0,000 yaitu $(0,000<0,1)$, maka $\mathrm{H}_{\mathrm{a}}$ diterima dan $\mathrm{H}_{\mathrm{o}}$ ditolak. Hasil signifikansi untuk variabel kualitas produk sebesar 0,067 yaitu $(0,067<0,1)$, maka $\mathrm{H}_{\mathrm{a}}$ diterima dan $\mathrm{H}_{\mathrm{o}}$ ditolak. Jadi dapat disimpulkan bahwa dari hasil uji Independent Sample T-Test terdapat perbedaan keputusan pembelian sepeda motor merek Yamaha dan Honda yang signifikansi dari segi harga, merek, dan kualitas produk.
\end{abstract}

Kata Kunci : Keputusan Pembelian, Harga, Merek, Kualitas Produk 


\section{PENDAHULUAN}

Pada era persaingan yang begitu ketat saat ini, manusia di tuntut untuk dapat menerapkan efisiensi dan efektifitas dalam semua aktivitasnya, begitu pula dalam hal mobilitas dari satu tempat ke tempat lain. Hal ini tentu akan berpengaruh terhadap pemilihan alat transportasi yang akan digunakan. Dalam kondisi saat ini, dari semua alat transportasi yang ada, sepeda motor menjadi favorit masyarakat karena dianggap paling efektif dan efisien. Berbagai macam produk sepeda motor yang beredar di pasaran, membuat para konsumen lebih teliti dalam memilih sepeda motor yang disukainya. Ada banyak pemain besar dalam industri ini, tetapi hanya dua dari mereka sebagai pemain besar dengan pangsa pasar yang signifikan. Sepeda motor Honda dan Yamaha adalah dua merek yang mendominasi industri motor.

Pilihan masyarakat ini tentu menjadi sebuah peluang besar bagi pelaku bisnis otomotif, terutama dibidang kendaraan bermotor roda dua, untuk terus meningkatkan penjualannya dengan penerapan strategi pemasaran yang tepat. Inovasi yang dapat memenuhi kebutuhan dan selera konsumen mutlak diperlukan jika pelaku bisnis tidak ingin kehilangan konsumennya serta menumbuhkan permintaan akan produknya.

Faktor yang memengaruhi peningkatan penjualan sangat beragam, baik faktor internal dari kegiatan pemasaran perusahaan (kualitas promosi, harga, dan desain) maupun faktor internal yang terkait dengan keputusan pembelian konsumen dalam memilih suatu produk. ${ }^{1}$ Dengan kemajuan teknologi dan ilmu pengetahuan yang semakin berkembang menyebabkan semakin banyaknya produk sejenis yang dihasilkan dan ditawarkan dimana salah satu pilihan tersebut harus disesuaikan dengan keinginan dan kebutuhan konsumen.

Menurut Badan Pusat Statistik pada Tahun 2008-2012 dijumpai perkembangan jumlah transportasi yang sangat pesat di negara Indonesia. Tingginya jumlah pembelian mobil dan sepeda motor baru oleh masyarakat merupakan faktor penyebab semakin meningkatnya jumlah kendaraan bermotor di jalan raya. Jumlah penjualan kendaraan bermotor roda dua dari tahun 2008 sampai dengan 2012 selalu mengalami peningkatan. Pada tahun 2012 penjualan sepeda motor mencapai 76.381 .183 unit, mengalami kenaikan dari penjualan sebelumnya.

Tingginya permintaan akan kendaraan bermotor di Indonesia yang setiap tahunnya terus bertambah. Hal ini berdampak semakin ketatnya persaingan dalam dunia bisnis khususnya pada bidang penjualan kendaraan bermotor diseluruh Indonesia karena setiap perusahaan senantiasa berusaha untuk mendapatkan pangsa pasar yang setiap bulannya diharapkan agar selalu berkembang. Perusahaan harus dapat menentukan strategi

\footnotetext{
${ }^{1}$ Morissan, Periklanan Komunikasi Pemasaran Terpadu (Jakarta: Kencana, 2010), hlm. 15.
} 
pemasaran yang baik dan cocok bagi perusahaannya agar usahanya dapat bertahan dan memenangi suatu persaingan dalam bisnis.

Saat ini industri otomotif di Indonesia, terutama untuk kendaraan roda dua, sedang mengalami kemajuan yang cukup pesat. Hal ini didukung oleh belum tersedianya kendaraan umum yang efisien bagi mobilitas masyarakat. Selain itu, kemudahan proses pembayaran dengan merebaknya perusahaan leasing juga mendorong masyarakat untuk membeli dan menggunakan sepeda motor sebagai alat transportasi.

Honda dan Yamaha sudah menjadi primadona di mata pecinta sepeda motor di tanah air, dikarenakan masyarakat tidak hanya mendengar dari mulut ke mulut akan kualitas dari kedua motor tersebut melainkan sudah dirasakan oleh konsumen sendiri. Hal ini dapat diperkuat berdasarkan data penjualan sepeda motor di Indonesia tahun 2011-2017 oleh AISI.

Dikutip dari data penjualan AISI, Honda masih menjadi pabrikan nomor satu. Disisi lain, Yamaha masih berada di bawah Honda. Dari segi harga, Yamaha dengan berbagai macam produk harga yang dikeluarkan untuk jenis yang sekelas lebih murah dari Honda. Dalam menghadapi persaingan yang semakin ketat maka industri sepeda motor harus mampu memberikan kepuasan terhadap konsumennya seperti menghasilkan produk dengan kualitas yang baik, dan tentunya dengan harga yang sesuai. ${ }^{2}$

Harga adalah sejumlah uang yang dibutuhkan untuk mendapatkan sejumlah barang dan jasa-jasa tertentu atau kombinasi dari keduanya. ${ }^{3}$ Harga merupakan satu-satunya unsurunsur marketing mix yang menghasilkan pendapatan penjualan, sedangkan unsur lainnya hanya unsur biaya saja. Secara tradisional, harga menjadi faktor yang paling dominan dalam keputusan pembelian. Namun, seiring dengan perbaikan kondisi ekonomi konsumen faktor non harga juga menjadi faktor yang penting dalam keputusan pembelian. Mulyono menyebutkan bahwa kualitas juga merupakan hal yang paling mendasar dari kepuasan konsumen dan kesuksesan dalam bersaing.

Selain itu, faktor lain yang memengaruhi keputusan pembelian adalah merek. Menurut Kotler "Merek adalah sebuah nama, istilah tanda, simbol atau rancangan atau bahkan kombinasi dari semuanya tadi, yang dimaksudkan untuk menyebutkan barang-barang atau jasa dari seorang atau sekelompok penjual agar terbedakan dari para pesaingnya”.4 Faktor promosi juga diperhatikan mengingat dewasa ini informasi menjadi hal yang sangat penting bagi konsumen. Sebagai salah satu dari bauran pemasaran, promosi memegang peranan yang tidak kecil dalam keputusan pembelian keputusan. Kotler mengartikan promosi sebagai proses komunikasi suatu perusahaan dengan pihak-pihak yang berkepentingan sekarang, dan yang akan datang. Promosi juga dapat diartikan sebagai koordinasi dari seluruh upaya yang

\footnotetext{
${ }^{2}$ Mas Muslim, Data AISI Penjualan Sepeda Motor Tahun 2011-2017 Honda. Diakses Selasa, 21 Nopember 2017 pukul 20.35 WIB.

${ }^{3}$ Indriyo Gitosudarmo, Manajemen Pemasaran (Jakarta: BPFE, 2008), hlm. 28.

${ }^{4}$ Danang Sunyoto, Dasar-Dasar Manajemen Pemasaran (Yogyakarta: CAPS, 2014), hlm. 102.
} 
dimulai pihak penjual untuk membangun berbagai saluran informasi dan persuasi untuk menjual barang dan jasa atau memperkenalkan suatu gagasan. ${ }^{5}$

Munculnya Juara Dunia Moto GP Jorge Lorenzo dan Valentino Rossi sebagai endorser Yamaha menjadi salah satu ajang promosi yang dapat meningkatkan penjualan, serta memilih slogan promosi yang tepat dan mudah di ingat oleh konsumen. Selain itu, promosi juga harus memberi informasi penting yang perlu diketahui oleh konsumen, karena betapa pun berkualitasnya suatu produk jika konsumen tidak mengetahuinya maka konsumen tidak akan membelinya.

Berdasarkan survei awal yang peneliti lakukan di Desa Aek Tuhul dengan jumlah penduduk 1576 jiwa, yang terdiri dari 392 KK. 6 Peneliti menemukan fakta bahwa dari 30 orang yang memiliki sepeda motor terdapat 10 orang yang menggunakan merek Yamaha dan 20 orang merek Honda. Faktor-faktor yang memengaruhi ke 30 orang tersebut dalam memilih sepeda motor diantaranya harga, promosi, merek, dan kualitas produk. ${ }^{7}$ Hal ini diperkuat dengan hasil wawancara peneliti dengan salah satu warga yang bernama Desi Kurnia Ningsih. Ibu yang memiliki dua orang anak ini menyebutkan bahwa keputusannya untuk membeli sepeda motor dipengaruhi oleh banyak hal, sudah tentu kebutuhan merupakan salah satu disamping faktor lain yang telah disebutkan. ${ }^{8}$

Dari 30 responden, 10 yang memutuskan untuk membeli sepeda motor Yamaha dan 20 lainnya memutuskan untuk membeli sepeda motor Honda. Konsumen dari kedua produk ini mengatakan bahwa banyak faktor yang menyebabkan mereka memutuskan untuk memilih merek tersebut. Namun, faktor yang paling menonjol di antaranya adalah: harga, merek, dan kualitas produk. ${ }^{9}$

Hal ini menunjukkan bahwa setiap konsumen memiliki berbagai faktor yang memengaruhi keputusan untuk membeli sepeda motor. Meskipun yang dibeli itu adalah sama-sama sepeda motor yang sangat dibutuhkan untuk meringankan aktivitas sehari-hari, namun setiap orang punya alasan yang berbeda. Karena faktor-faktor yang paling mendominasi keputusan pembelian sepeda motor merek Yamaha dan Honda adalah harga, merek, dan kualitas produk, maka nantinya peneliti akan berfokus pada ketiga faktor ini saja.

Berdasarkan uraian di atas, maka penelitian ini menjadi menarik untuk dilakukan, sejauh mana harga, merek, dan kualitas produk terhadap keputusan pembelian sepeda Motor merek Yamaha dan Honda. Sehingga peneliti tertarik untuk mengadakan penelitian dengan

\footnotetext{
${ }^{5}$ Morissan, Op. Cit., hlm. 16.

${ }^{6}$ Buku DRT (Daftar Rumah Tangga) Desa Aek Tuhul. Kec. Psp Batunadua.

${ }^{7}$ Hasil survei yang dilakukan peneliti (pra angket) pada hari Sabtu, 04 Maret 2017, pukul 17.00 WIB.

${ }^{8}$ Hasil wawancara dengan Ibu Desi K. Ningsih, Jum'at 03 Maret 2017, pukul 17.00 WIB.

${ }^{9}$ Hasil observasi awal (Aek Tuhul Kecamatan Padangsidimpuan Batunadua, Sabtu 04 Maret 2017, pukul 17.00 WIB).
} 
mengangkat judul "ANALISIS PERBANDINGAN KEPUTUSAN PEMBELIAN SEPEDA MOTOR MEREK YAMAHA DAN HONDA".

\section{LANDASAN TEORI}

\section{Pengertian Keputusan Membeli}

Keputusan adalah seleksi terhadap dua pilihan alternatif atau lebih. ${ }^{10}$ Dengan perkataan lain, pilihan alternatif harus tersedia bagi seseorang ketika mengambil keputusan. Keputusan membeli adalah tindakan dari konsumen untuk mau membeli atau tidak terhadap produk. Jika seseorang mempunyai pilihan antara melakukan pembelian dan tidak melakukan pembelian, pilihan antara merek X dan merek $\mathrm{Y}$, atau pilihan untuk menggunakan waktu mengerjakan "A" atau "B" orang tersebut berada dalam posisi untuk mengambil keputusan. ${ }^{11}$ Kebutuhan merupakan konsep yang lebih bernilai dari sekedar keinginan. Keinginan ditetapkan berdasarkan utility, tetapi need didasarkan atas konsep maslahah. Tujuan Syari’ah adalah menyejahterakan manusia (maslahah al 'ibad). Kandungan maslahah terdiri dari manfaat dan berkah. Demikian pula dalam hal perilaku konsumsi, seorang konsumen akan mempertimbangkan manfaat dan berkah yang dihasilkan dari kegiatan konsumsinya. ${ }^{12}$

\section{Harga}

Harga merupakan salah satu aspek penting dalam kegiatan marketing mix.13 Menurut Kotler dan Amstrong, harga adalah jumlah uang yang dibebankan atas produk atau jasa, jumlah dari nilai yang ditukar konsumen atas manfaat-manfaat karena memiliki atau menggunakan produk atau jasa tersebut. ${ }^{14}$ Harga merupakan satu-satunya unsur bauran pemasaran yang memberikan pemasukan atau pendapatan bagi perusahaan, sedangkan ketiga unsur lainnya berupa produk, distribusi, dan promosi membutuhkan pengeluaran dana.

Ibnu Taimiyah merupakan orang yang pertama kali menaruh perhatian khusus terhadap permasalahan harga yang adil. Dalam membahas persoalan yang berkaitan dengan harga, ia sering kali menggunakan dua istilah, yakni kompensasi yang setara ('iwadh al-mitsl) dan harga yang setara (tsaman al-mitsl). Ibnu Taimiyah menganggap harga yang setara sebagai harga yang adil. ${ }^{15}$

${ }^{10}$ Etta Mamang Sangadji, Perilaku Konsumen (Yogyakarta: C.V ANDI OFFSET, 2013), hlm. 120.

${ }^{11}$ Leon Schiffman, Perilaku Konsumen (Jakarta: PT Indeks, 2008), hlm. 485.

${ }^{12}$ M. Nur Rianto Al-Arif, Dasar-Dasar Ekonomi Islam (Solo: PT Era Adicitra Intermedia, 2011), hlm. 153. hlm. 52.

${ }^{13}$ Kasmir dan Jakfar, Studi Kelayakan Bisnis (Jakarta: KENCANA PRENADA MEDIA GROUP, 2004),

${ }^{14}$ Danang Sunyoto, Dasar-Dasar Manajemen Pemasaran (Yogyakarta: CAPS, 2014), hlm. 131.

${ }^{15} \mathrm{H}$. Adiwarman Azwar Karim, Sejarah Pemikiran Islam (Jakarta:PT RajaGrafindo Persada, 2004), hlm. 332-333. 


\section{Merek}

Dalam mengembangkan strategi pemasaran untuk produk individual, penjual menghadapi masalah pemberian merek. Merek dapat menambah nilai produk dan karena itu merupakan aspek instrinsik dalam strategi produk. Menurut Kamus Besar Bahasa Indonesia "Merek adalah tanda yang dikenakan oleh pengusaha (pabrik, produsen, dan sebagainya) pada barang yang dihasilkan sebagai tanda pengenal, cap (tanda) yang menjadi pengenal untuk menyatakan nama, kegagahan, keunggulan, kualitas”.

\section{Kualitas Produk}

Kualitas adalah salah satu alat penting bagi pemasar untuk menetapkan posisi. Kualitas bisa jadi merupakan hal yang paling dicari oleh konsumen ketika mereka memilih produk yang akan digunakan. Kualitas adalah keseluruhan fitur dan sifat produk atau pelayanan yang berpengaruh pada kemampuannya untuk memuaskan kebutuhan yang dinyatakan atau yang tersirat. Dalam penelitian ini kualitas produk diartikan sebagai penilaian konsumen mengenai atribut dalam produk yang akan memenuhi kebutuhan dan memberi manfaat bagi mereka. ${ }^{16}$

\section{METODOLOGI PENELITIAN}

Penelitian ini dilakukan di Desa Aek Tuhul Kec. Padangsidimpuan Batunadua. Adapun waktu penelitian ini akan dilakukan bulan Desember-Juli 2018.

Jenis penelitian yang digunakan dalam penelitian ini adalah penelitian kuantitatif. Penelitian dengan pendekatan kuantitatif menekankan analisisnya pada data-data numerical (angka), mulai dari pengumpulan data, penafsiran terhadap data tersebut serta penampilan hasilnya yang di olah dengan metode statistik.17

Menurut metodenya penelitian ini menggunakan metode komparatif (perbandingan) dan merupakan salah satu bagian dari statistik parametrik dengan menggunakan uji t-test. Penelitian komparatif adalah penelitian yang dilakukan untuk membandingkan nilai satu variabel dengan variabel lainnya dalam waktu yang berbeda. Penelitian ini menggunakan lebih dari satu sampel.18

\footnotetext{
16 Tamrin Abdullah, Manajemen Pemasaran (Jakarta: PT. Raja Grafindo Persada, 2012), hlm. 159.

${ }^{17}$ Syaifuddin Azwar, Metode Penelitian (Yogyakarta: Pustaka Pelajar, 2004), hlm. 5.

${ }^{18}$ Iqbal Hasan, Analisis Data Penelitian dengan Statistik (Jakarta: PT Bumi Aksara, 2008), hlm. 7.
} 


\section{HASIL PENELITIAN}

Penelitian ini berjudul "Analisis Perbandingan Keputusan Pembelian Sepeda Motor Merek Yamaha dan Honda (Studi Kasus Desa Aek Tuhul Kecamatan Padangsidimpuan Batunadua)". Setelah melewati tahap-tahap, pembeli akan menentukan sikap dalam pengambilan keputusan apakah membeli atau tidak. Sedangkan faktor-faktor yang memengaruhi keputusan pembelian yaitu harga, merek dan kualitas produk yang semuanya saling memengaruhi. Setelah membeli suatu produk, konsumen akan mengalami beberapa tingkat kepuasan atau ketidakpuasan.

Setelah melalui berbagai analisis data terhadap model, maka dapat dinyatakan bahwa berdasarkan hasil Test Friedman pada sepeda motor merek Yamaha dengan taraf signifikan o,1 dimana Chi-kuadrat hitung 30,179 > Chi-kuadarat tabel 24,769. Dengan demikan $\mathrm{H}_{\mathrm{a}}$ diterima dan $\mathrm{H}_{\mathrm{o}}$ ditolak. Adapun variabel kualitas produk berpengaruh besar terhadap keputusan pembelian sepeda motor merek Yamaha sebesar 3,00. Variabel merek berpengaruh sebesar 1,85 dan variabel harga berpengaruh kecil terhadap keputusan pembelian sepeda motor Yamaha yaitu sebesar 1,15.

Berdasarkan hasil test Friedman pada sepeda motor merek Honda dengan taraf signifikan 0,1 dimana Chi-kuadrat hitung 73,817 > chi-kuadrat tabel 66,548. Dengan demikian $\mathrm{H}_{\mathrm{a}}$ diterima dan $\mathrm{H}_{\mathrm{o}}$ ditolak. Adapun variabel kualitas produk berpengaruh besar terhadap keputusan pembelian sepeda motor merek Honda sebesar 2,76. Variabel merek berpengaruh sebesar 2,11 dan variabel harga berpengaruh kecil terhadap keputusan pembelian sepeda motor Honda yaitu sebesar 1,12. sementara variabel merek berpengaruh sebesar 2,11. Dari penjelasan di atas dapat disimpulkan bahwa adanya perbedaan keputusan pembelian sepeda motor merek Yamaha dan Honda, baik dari harga, merek, maupun kualitas produk.

Berdasarkan hasil penelitian peneliti di atas, maka dapat dinyatakan bahwa hipotesis yang terdapat pada bab II dapat diterima yaitu adanya perbedaan antara variabel harga, merek, dan kualitas produk terhadap keputusan pembelian sepeda motor merek Yamaha dan Honda. Hal ini juga sesuai dengan keputusan pembelian yang peneliti jelaskan pada bab II berdasarkan teori Leon Schiffman dan Leslie Kanuk dalam bukunya "Perilaku Konsumen" yaitu sebuah keputusan adalah seleksi terhadap dua pilihan alternatif atau lebih. Dengan perkataan lain, pilihan alternatif harus tersedia bagi seseorang ketika mengambil keputusan. Jika seseorang mempunya pilihan antara melakukan pembelian dan tidak melakukan pembelian, pilihan antara merek $\mathrm{X}$ dan merek $\mathrm{Y}$, atau pilihan untuk menggunakan waktu mengerjakan "A" atau "B". 


\section{DAFTAR PUSTAKA}

Abdul Hamid, Buku Panduan Penulisan Skripsi, Jakarta: FEISH UIN, 2007.

Ali Hasan, Marketing, Yogyakarta: Media Pressindo, 2008.

Danang Sunyoto,Dasar-Dasar Manajemen Pemasaran, Yogyakarta: CAPS, 2014.

Daftar Rumah Tangga (DRT) Desa Aek Tuhul, Kecamatan Padangsidimpuan Batunadua.

Etta Mamang Sanagdji,Perilaku Konsumen, Yogyakarta: C.V ANDI OFFSET, 2013.

Hartono, Statistik Untuk Penelitian, Pekanbaru: $\mathrm{LSFK}_{2} \mathrm{P}, 2004$.

Hendri Tanjung dan Abrista Devi,Metodologi Penelitian Ekonomi Islam,Jakarta: Gramata Publishing, 2013.

Hasil survei yang dilakukan peneliti (pra angket) pada hari Sabtu, 04 Maret 2017, pukul 17.00 WIB.

Hasil wawancara dengan Ibu Sariana, Jum'at 03 Maret 2017, pukul 17.0o WIB.

http://www.motor-yamaha.co.id

http://www. astra-honda.com/corporate

Indriyo Gitosudarmo,Manajemen Pemasaran, Jakarta: BPFE, 2008.

Iqbal Hasan, Analisis Data Penelitian Dengan Statistik, Jakarta: PT Bumi Aksara, 2008.

Juliansyah Noor,Metodologi Penelitian: Skripsi, Tesis, Disertasi, dan Karya Ilmiah, Jakarta: Kencana, 2011.

Kasmir dan Jakfar, Studi Kelayakan Bisnis, Jakarta: KENCANA PRENADA MEDIA GROUP, 2010.

Kotler, Philip dan Kevin Lane,Manajemen Pemasaran,Jakarta: PT Mancanan Jaya Cemerlang, 2007.

Maman Abdurrahman dan Sambas Ali Muhidin,Panduan Praktis Memahami Penelitian, Bandung: CV. Pustaka Setia, 2011.

Mas Muslim, Data AISI Penjualan Sepeda Motor Tahun 2006-2017 Honda.Diakses Selasa, 21 Nopember 2017 pukul 20.35 WIB.

Muhammad,Metodologi Penelitian Islam: Pendekatan Kuantitatif,Jakarta: Rajawali Pers, 2008.

Morissan,Periklanana Komunikasi Pemasaran Terpadu, Jakarta: Kencana, 2010.

M. Quraish Shihab, Tafsir Al-Mishbah: Pesan, Kesan, dan Keserasian al-Qur'an, Jakarta: Lentera Hati, 2002.

Rangkuti, Ahmad Nizar,Metode Penelitian Pendidikan, Bandung: Citapustaka Media, 2016. 
Sarwono Jonathan,Metode Riset Skripsi: Pendekatan Kuantitatif Menggunakan Prosedur SPSS, Jakarta: PT. Elex Media Komputind, 2012.

Schiffman, Leon G. dan Leslie Lazar Kanuk, Perilaku Konsumen,Indonesia: PT. Indeks, 2008.

Suarsimi Arikunto,Prosedur Penelitian Suatu Pendekatan Praktis,Jakarta: Rineka Cipta, 2010.

Sugiyono,Metode Penelitian Bisnis, Bandung: CV. Alfabeta, 2005.

Sugiyono,Metode Penelitian Kuantitatif dan Kualitatif, Bandung: CV. Alfabeta, 2009.

Sugiyono dan Agus Susanto,Cara Mudah Belajar SPSS dan LISREL Teori dan Aplikasi Untuk Analisis Data Penelitian,Bandung: ALFABETA, 2015.

Syaifuddin Azwar,Metode Penelitian, Yogyakarta: Pustaka Pelajar, 2004.

Tamrin Abdullah,Manajemen Pemasaran, Jakarta: PT. Raja Grafindo Persada, 2012.

William A. McEachem, Ekonomi Mikro: Pendekatan Kontemporer, Jakarta: Salemba Empat, 2001.

Zulganef,Metodologi Penelitian Sosial dan Bisnis,Yogyakarta: Graha Ilmu, 2008. 